WHAT IS A CLASSIC? 



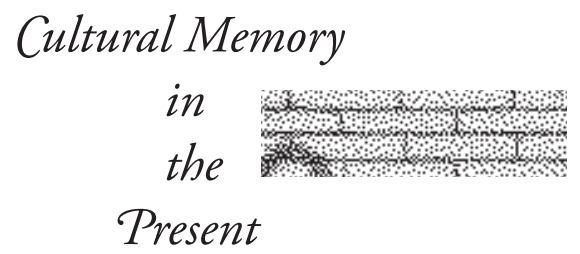

Hent de Vries, Editor 



\title{
WHAT IS A CLASSIC?
}

Postcolonial Rewriting and Invention of the Canon

\author{
Ankhi Mukherjee
}


Stanford University Press

Stanford, California

(C) 2014 by the Board of Trustees of the Leland Stanford Junior University.

All rights reserved.

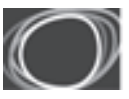

\section{Arts \& Humanities}

Research Council

This book was written with the support of the Arts and Humanities Research Council (AHRC). For further information on the AHRC, please go to: www.ahrc .ac.uk.

No part of this book may be reproduced or transmitted in any form or by any means, electronic or mechanical, including photocopying and recording, or in any information storage or retrieval system without the prior written permission of Stanford University Press.

Printed in the United States of America on acid-free, archival-quality paper

Library of Congress Cataloging-in-Publication Data

Mukherjee, Ankhi, author.

What is a classic? : postcolonial rewriting and invention of the canon / Ankhi Mukherjee.

pages $\mathrm{cm} \mathrm{--} \mathrm{(Cultural} \mathrm{memory} \mathrm{in} \mathrm{the} \mathrm{present)}$

Includes bibliographical references and index.

ISBN 978-0-8047-852I-I (cloth : alk. paper)

I. English literature--20th century--History and criticism. 2. English literature-2Ist century--History and criticism. 3. Postcolonialism in literature. 4. Canon

(Literature) 5. Criticism. I. Title. II. Series: Cultural memory in the present. PR478.P665M85 20I4

820.I--dc23

2013026231

Typeset by Bruce Lundquist in II/13.5 Adobe Garamond 
For Derek Attridge 
